\title{
Peran Pemuka Pendapat Dalam Program Bedah Rumah Di Desa Sukorambi Jember
}

\author{
Sudahri*Raden Arsali** \\ *Dosen Fisipol Unmuh Jember \\ **Alumnus Fisipol Unmuh Jember
}

\begin{abstract}
Abstrak
Program bedah rumah di Jember mendapatkan perhatian yang sangat luas terutama bagi masyarakat pedesaan. Sosok pemuka pendapat seperti kiai dan perangkat desa mempunyai peranan yang berarti dalam program tersebut. Penelitian ini bertujuan untuk mengetahui peran pemuka pendapat dan hambatan yang dihadapi dalam program bedah rumah. Jenis penelitian ini adalah jenis penelitian deskriptif kualitatif, sedangkan teori yang dipakai adalah teori yang berkaitan dengan opinion leader. Dari hasil penelitian diperoleh kesimpulan Peran pemuka pendapat di desa Sukorambi Jember dalam hal ini Perangkat desa, Kyai/Bindereh dan tokoh masyarakat sangat dirasa oleh masyarakat, sedangkan kendala yang dihadapi adalah lemahnya komunikasi yang harmonis antara pemuka pendapat dengan perangkat desa yang disebabkan oleh kepetingan yang kurang serasi.
\end{abstract}

Kata Kunci : Pemuka pendapat, Program Bedah Rumah

\begin{abstract}
S
Surgical house program in Jember get vast attention especially for rural society. The figure of the opinion leaders such as teacher of Islam and Councilor has an important a role in that program. This research has aims to know a role of opinion leaders and the obstacles that encountered in surgical house program. The type of this research is descriptive of qualitative research, but the theory that used is the theory that relate to the opinion leader. The conclusion of this research is a role of opinion leaders in the village of Sukorambi Jember, Councilor, teacher of Islam and society figures very felt by society, whereas the obstacles that gotten is the weakness of harmonious communication between the opinion leaders with the Councilor, because they are less harmonious.
\end{abstract}

Keywords: Opinion leaders, Surgical House Programs 


\section{Pendahuluan}

Perumahan merupakan kebutuhan dasar manusia yang berperan dalam menjaga kelangsungan kehidupan dan penghidupan. Dimana hak atas perumahan adalah hak setiap orang untuk memperoleh secara berkelanjutan rumah yang layak dengan komunitas yang aman dan bermartabat. Layak dalam hal ini meliputi jaminan keamanan dan hukum, mudah didapat dari segi keuangan, mendukung untuk pelaksanaan aktifitas hidup seharihari, atau hal lain yang membuat kehidupan penghuninya bermartabat sebagai manusia (http://www.setneg.go.id).

Indonesia sendiri telah menetapkan dalam pasal 28 ayat 1 Undang-Undang Dasar RI tahun 1945, bahwa setiap orang memiliki hak hidup sejahtera lahir dan batin, bertempat tinggal dan mendapatkan lingkungan hidup yang baik dan sehat. Oleh karenanya, rumah sebagai wadah tempat tinggal perseorangan ataupun dalam entitas sosial baik dalam bentuk keluarga atau lainnya merupakan hak setiap orang. Karena secara fungsional rumah dijadikan sebagai wadah untuk berlindung dari tantangan alam dan ancaman binatang, sekaligus wadah interaksi sosial keluarga dan pada kasus tertentu mewadahi aktivitas ekonomi penghuninya. Jadi, dapat dikatakan, hak perumahan secara nasional didefinisikan sebagai hak bagi setiap orang untuk mendapatkan akses menghuni rumah yang layak dalam suatu komunitas yang aman dan bermartabat secara berkelanjutan.

$$
\text { Pekerjaan besar dirancang oleh }
$$
Kementerian Sosial pada tahun 2015 ini, yaitu "Bedah Rumah" pada lebih dari 1000 titik."Bedah Rumah" adalah model pengembangan pemberdayaan keluarga miskin melalui rehabilitasi rumah tidak layak huni. Kementerian Sosial mendata sebanyak 2,3 juta rumah tidak layak huni di seluruh Indonesia. Tetapi anggaran Kementerian Sosial setiap tahunnya hanya mampu untuk membedah 15.000 unit rumah. Artinya, pekerjaan besar tersebut akan selesai dalam 153 tahun dengan asumsi besarnya anggaran per tahun tetap.

Untuk itu diperlukan sumber anggaran di luar APBN, yaitu dari APBD I, APBD II, dunia usaha, dan donatur dalam mau pun luar negeri. Semua pihak yang memiliki sumber daya, seharusnya mendukung pencapaian tujuan tersebut. Gubernur dan Wali Kota/Bupati diharapkan pandai-pandai mencari peluang dan terobosan dalam mendukung program "Bedah Kampung" tersebut. Sebagaimana dianamatkan undang-undang, bahwa bidang sosial (kesejahteraan sosial) merupakan bidang pembangunan yang juga menjadi urusan wajib Pemda.

Masyarakat Berpenghasilan Rendah 
(MBR) 7 Kecamatan di Jember mendapat Program Bantuan Stimulan Pembangunan Swadaya (BSPS) Kementrian Perumahan Rakyat (Kemenpera). Warga yang tersebar di Delapan Desa dan Satu Kelurahan ini, masing-masing mendapatkan bantuan sebesar 7,5 juta. Salah satunya adalah di Desa Sukorambi-Jember.Bantuan Program BSPS diberikan langsung kepada masyarakat melalui Bank BRI. Dari dana itu dipotong biaya pembuatan SPJ foto rumah, ATK dan ongkos tukang sehingga jatuhnya kisaran 6,3 - 6,5 jutaan" Informasi yang diterima media Radar Jember mengatakan bahwa jumlah penerima MBR di Jember sebanyak, 1,704, tersebar di 8 Desa dan 1 Kelurahan di 7 Kecamatan. Untuk Sukorambi berada di Dusun Manggis, Curahdami dan Kerajan.

Tetapi tidak semua masyarakat penerima Dana Pembangunan BSPS (Bantuan Stimulan Program Swadaya) yang digelontorkan pihak Kementerian Perumahan Rakyat merasakan manfaatnya, Bahkan sebagian masyarakat penerima program tersebut justru terlantar, belum tersentuh program tersebut. Hal ini paling sering terjadi lantara adanya ketidak tepatan sasaran kepala desa setempat dalam membidik penerima bantuan.

Pelaksanaan pembangunan nasional akan terwujud apabila didukung oleh situasi dan kondisi yang tertib dalam bedah rumah di Desa Sukorambi- menyelenggarakan pemerintahan baik dipusat maupun di daerah termasuk di tingkat desa dan kelurahan. Dan penyelenggaraan pemerintahan desa dan kelurahan menurut UU No. 5 Tahun 1979 diarahkan agar mampu melayani dan mengayomi masyarakat, mampu menggerakan prakarsa dan partisipasi masyarakat, dalam pembangunan. Pembangunan desa akan berhasil baik apabila didukung oleh partisipasi seluruh warga masyarakat. Dan optimalisasi pembangunan sangat dipengaruhi oleh bagaimana fungsi yang dijalankan oleh pihak pemerintah sebagai koordinator pelaksanaan pembangunan. Dalam hal ini pemerintah harus mampu mengkoordinasikan berbagai unit dalam pemerintahan agar dapat mendayagunakan fungsi mereka dengan baik dan memberikan kontribusi yang nyata bagi proses pembangunan.

Dari kondisi riil yang ada, bahwa Kepala desa sebagai salah satu pemuka pendapat adalah kunci dari pendeskripsian keberhasilan kepemimpinan desa. Kepala Desa menjadi kunci dari keefektifan sasaran untuk diberikan bantuan sosial pemerintah yaitu program "Bedah rumah". Hal inilah yang melatarbelakangi peneliti untuk meneliti mengenai peran Pemuka Pendapat dalam Keefektifan program

Kabupaten Jember dilihat dari sudut 
ketepatan sasaran pelaksanan progam pengentasan kemiskinan dan keefektifan program ini dalam masyarakat.

\section{Rumusan Masalah}

a. Bagaimanakah peran pemuka pendapat Sukorambi-Jember dalam program "Bedah Rumah" di Desa Sukorambi?

b. Hambatan apa saja yang dirasakan oleh pemuka pendapat dalam program "Bedah Rumah"?

\section{Tinjauan Pustaka}

\section{Pemuka Pendapat}

Pemuka pendapat (opinion leader) adalah seseorang yang dipercaya untuk menyampaikan informasi dan menyatakan pendapatnya kepada masyarakat. Pemuka pendapat dapat melekat pada kehidupan di perkotaan, maupun di pedesaan. Masyarakat desa mengenal pemuka pendapat seperti kyai, dukun, tetua kampung, dan pemuka adat. Ambil contoh kyai. Kyai adalah seorang pemuka pendapat yang bersifat polimorfik, di mana ia menguasai lebih dari satu permasalahan. Seorang pemuka pendapat di pedesaan dimintai pendapatnya oleh masyarakat sekitar mengenai suatu hal, dan dampaknya adalah untuk mempengaruhi pola tingkah laku masyarakat secara formal. Misalnya saja, seorang kyai tidak hanya dimintai pendapat untuk mengobati penyakit, tetapi juga hal lain seperti bercocok tanam dan perjodohan (Nurudin, 2008).

Tidak seperti di pedesaan di mana masyarakatnya memiliki tingkat yang rendah baik terhadap pendidikan maupun pengenalan media, masyarakat perkotaan lebih maju tingkat pendidikannya (melek huruf) serta pengenalannya terhadap media massa. Hal ini menyebabkan masyarakat perkotaan lebih selektif terhadap pernyataan pemuka pendapat. Faktanya bahwa masyarakat perkotaan dapat langsung mengakses media massa secara langsung (pemimpin pendapat berfungsi sebagai perantara). Media massa menjadi monopoli pemimpin pendapat, di mana umpan balik yang didapat dari media massa, akan langsung mempengaruhi audiens. Model komunikasi yang terjadi demikian adalah model alir banyak tahap (Nurudin,2008). Namun, bukan berarti pemuka pendapat tidak berperan sama sekali pada masyarakat perkotaan. pemuka pendapat di perkotaan berkembang di dalam kehidupan politik dan sosial.

\section{Karakteristik Pemuka Pendapat}

Opinion leader adalah orang yang mempunyai keungulan dari masyarakat kebanyakan. Adapun karakteristik tersebut menurut Wilcox (2001) adalah :

a. Lebih tinggi pendidikan formalnya dibanding dengan anggota masyarakat lainnya. 
b. lebih tinggi status sosial ekonominya. (SSE)

c. lebih inovatif dalam menerima dan mengambil ide baru

d. Lebih tinggi pengenalan medianya (media exposure)

e. Kemampuan empatinya lebih besar

f. Partisipasinya lebih besar.

g. Lebih Kosmopolit (mempunyai pengetahuan dan wawasan yang luas).

Ruch (2002) juga mengatakan syarat seorang pemimipin (termasuk pemimpin opini):

a. social perception, artinya seorang pemimpin harus dapat memiliki ketajaman dalam menghadapi situasi.

b. Ability in abstrac thinking, artinya pemimpin harus memiliki kecakapan secara abstrak terhadap masalah yang dihadapi.

c. Emotional stability, artinya pemimpin harus memiliki perasaan stabil, tidak mudah terkena pengaruh dari luar (yang tidak dinyakini dan bertoloak belakang dengan kenyakinan masyarakat). (Santoso, 1992).

Pada umumnya ciri-ciri yang melekat pada opinion leader tidak bisa dilekatkan secara tajam pada para pemimpin desa. Sebab adakalanya batasan yang melekat tersebut sangat tipis sekali antara opinion leader dengan followesnya.
Dengan demikian tidak bisa dikatakan bahwa ciri-ciri itu melekat pada opinion leader. Sedangkan masyarakat tidak mempunyai ciri-ciri tersebut, salah satu keunggulan opinion leader dibanding dengan masyarakat kebanyakan adalah opinion leader itu lebih mudah menyesuaikan diri dengan masyarakatnya, lebih kompeten dan lebih tahu memelihara norma yang ada. Menurut Homas (1961), "Seorang yang memiliki status sosial yang tinggi (pemimin pendapat) akan senantiasa memelihara nilai-nilai serta norma kelompoknya sebagai syarat minimal mempertahankan statusnya".

$$
\text { Menurut Rogers (1973) ada tiga }
$$
cara mengukur dan mengetahui adanya opinion leader yaitu :

a. Metode Sosiometrik

Dalam metode ini, masyarakat ditanya kepada siapa mereka meminta nasihat atau mencari informasi mengenai masalah kemasyarakatan yang dihadapinya. Misalnya masalah itu mengenai difusi inovasi, kepada masyarakat diajukan pertanyaan: "dari mana anda memperoleh informasi tentang difusi inovasi?" jadi orang yang paling banyak mengetahui dan dimintai nasihat tenteng masalah tersebut dialah yang disebut sebagai opinion leader.

\section{b. Informast Ratting}

Metode ini mengajukan pertanyaan 
tertentu kepada orang/responden yang dianggap sebagai key informants dalam masyarakat mengenai siapa yang dianggap masyarakat sebagai pemimpin mereka. Jadi dalam hal ini responden tersebut haruslah jeli dalam mimilih siapa yang benar-benar harus memimpin dalam masyarakat tersebut. Dari segi kepribadian, pendidikan, serta tindakan yang dilakukannya terhadap masyarakat tersebut.

\section{c. Self Designing Method}

Metode ini mengajukan pertanyaan kepada responden dan meminta tendensi orang lain untuk menunjuk siapa yang mempunyai pengaruh. Misalnya. Apakah seseorang yang memerlukan suatu informasi perlu meminta keterangan kepada ibu /bapak. Jika jawabannya tidak maka hal tersebut belum menunjukkan siapa yang sering dimintai keterangan. Hal ini sangat bergantung kepada ketepatan (akurasi) responden untuk mengindentifikasi dirinya sebagai pemimpin.

\section{Jenis Pemuka Pendapat}

Istilah opinion leader menjadi perbincangan dalam literatur komunikasi sekitar tahun 1950-1960-an sebelumnya literatur komunikais sering digunakan katakata influentials, influencers atau tastemakers untuk menyebut opinion leader. Kemudian kata opinion leader lebih sering dikenal dimasyarakat pedesaan, sebab pada saat itu tingkat media masih rendah serta pendidikan yang belum maju. Jadi kebutuhan akan informasi dipedesaan diterima dari mereka yang mempunyai pemahaman yang tinggi serta kebutuhan akan media yang tidak rendah.

Ada dua pengelompokan opinion leader menurut Wilcox (2001):

\section{a. Opinion Leader Aktif (Opinion Giving)}

Disini para opinion leader tersebut sengaja mencari penerima atau followers untuk mengumumkan atau mensosialisasikan suatu informasi. Contoh : saat adanya program KB (Keluarga Berencana) yang bertujuan menegendalikan pertumbuhan penduduk. Tapi bagi masyarakat desa hal ini masih terlalu baru dan mereka belum mengenal apa itu KB sebenarnya, maka disini peranan opinion leader tersebut dituntun untuk menyampaikan informasi bahwa program KB ini bertujuan penting bagi kelangsungan masyarakat dipedesaan.

b. Opinion Leader Pasif (Opinion Seeking)

Dalam hal ini followers lebih aktif mencari sumber informasinya kepada opinion leader, sehubungan dengan permasalahan yang dihadapi seperti halnya contoh diatas tersebut.

\section{Pemuka Pendapat di Indonesia}

Sebagaimana sudah diketahui sebelumnya, kajian tentang pemimpin 
opini ini awalnya muncul di Amerika seperti yang ditunjukkan oleh Paul Lazarefeld dan kawan-kawan. Oleh karena itu model-model arus informasi yang mendekati pembahasan pemimpin opini ini adalah model two step flow. Artinya media massa tidak langsung mengenai audiencenya tetapi melalui pemimpin opininya. Kemudian informasi yang didapatkan tadi disampaikan kepada para pengikutnya.

Maksudnya pemuka pendapat disini adalah seseorang yang relatif dapat mempengaruhi sikap dan tigkah laku orang lain untuk bertindak dalam suatu tata cara tertentu. Tapi seiring dengan tingkat perkembangan media massa dan zaman. Lambat laun pemimpin opini ini ditinggalkan karena para audiencenya (pengikut) telah menentukan sikap dan perilaku sendiri, sebab secara tidak langsung mereka telah mampu mengaskes media massa.

\section{Pemuka Pendapat dalam Komunikasi}

Opinionleaderl pemuka pendapat menjadi salah satu unsur yang sangat mempengaruhi arus komunikasi. Khususnya dipedesaan berbagai perubahan dan kemajuan masyarakat sangat ditentukan oleh opinion leader. Misalnya pemimpin opini bisa berperan memotivasi masyarakat agar ikut serta secara aktif apa yang dilakuakan oleh pemuka pendapat dalam pembangunan, untuk itulah selayaknya pemerintah memberikan perhatian khusus terhadap pemuka pendapat ini. Bukan sebaliknya malah menjatuhkan opinion leader tersebut. Misalnya tentang kepercayaan masyarakat pada program pembangunan, selayaknya pemerintah memfungsikan peran opinion leader sebagai tokoh sentral dalam pembanguanan di pedesaan.

Opinion leader bukanlah manusia yang serba tau akan segala hal, tetapi kelebihannya adalah bahwa mereka diangap orang yang lebih peka dan in group serta tahu adat kebiasaamn masyarakat. Mereka memiliki jiwa sosial yang tinggi serta selalu siap memantu perubahan sosial di lingkungannya. Di desa ada suatu kecenderungan dalam masyarakat, dimana warga masyarakat akan lebih sering berkomunikasi sesama mereka dengan memilih tingkat pendidikan yang tidak terlalu tinggi. Misalnya mereka akan lebih tertarik dengan individu yang hanya lulusan SD dan SMP dibanding dengan lulusan universitas. Sebagaimana yang dikatakan Everett M. Roger dan Shoemaker "bahwa orang - orang yang paling tinggi status sosialnya dalam sisitem sosial jarang sekali untuk berinteraksi langsung dengan orangorang yang paling rendah status sosialnya.

Dalam penelitian Van de Ban (1963)

di Belanda menemuan fakta bahwa cenderung diikuti oleh masyarakat. Pemuka 
pendapat mempunyai gradasi homofili yan lebih baik dibanding dengan pihak lain. Homofili artinya suatu tingkat dimana pasanga individu yang berinteraksi sepadan dalam hal tertentu, seperti suatu kepercayaan, nilai-nilai, pendidikan dan status sosial. Homofili kebalikan kata dari heterofili. Jika homofili dalam sistem sosial itu tinggi, maka komunikasi akan sangat mudah untuk dilakukan, tapi heterofili suatu interaksi dalam berkomunikasi yang belum mempunyai dasar dalam bentuk kepercayaan untuk melakukan hal tersebut.

Komunikasi yang terbagi menjadi empat level jika diamati akan melibatkan peran opinion leader. Pada level interpersonal, sekalipun sangat terbatas pasti tetap ada yang lebih dominan. Begitu juga dalam komunikasi kelompok, komunikasi organisasi dan komunikasi massa.

Pada komunikasi massa, opinion leader secara langsung akan diduduki oleh pelaku komunikasi oganisasi, demikian juga komunikasi organisasi memiliki opinion leader dari level- level dibawahnya. Hal yang mendasar yaitu bahwa opinion leader memiliki posisi yang cukup kuat untuk mempengaruhi khalayak. Kekuatan itu dapat berasal dari factor budaya, agama atau pengalaman.

Faktor senioritas yang cukup berpengaruh di Indonesia pada umumnya dikeluarkan oleh Majelis Alim dan masyarakat pedesaan pada khususnya apabila dikaji dalam teori komunikasi akan masuk pada aliran mikro khususnya effect research. Effect Research mengaalisas bagaimana efek media mampu menjangkau khalayak.

Kehadiran sosok opinion leader menunjukkan adanya keterlibatan yang kuat dari komunikasi interpersonal dalam proses komnuasi massa secara keseluruhan. Opinion leader itu sendiri merupakan individu dalam masyarakat yang menerima informasi dari media dan meneruskannya dalam kelompok asalnya.

Melalui media massa yang saai ini sudah semakin banyak berkembang dengan segementasi- segmentasi yang semakin sempit, masyarakat mulai dihadapkan pada kondisi untuk memilih. Dengan demikian arus efek media bisa langsung sampai pada audiens. Namun sekalipun demikian, adakalanya khalayak sangat tergantung pada informasi yang disampaikan oleh pihak tertentu yang dianggap berwenang. Sebagai contoh, saat kasus beberapa aliran sesat marak terjadi di Indonesia, secara legal dalam undang- undang sudah diatur ketentuan suatu aliran dikatakan sesat atau tidaknya. Resminya, aturan Negara berada di atas segalanya tetapi pada praktiknya ada hal yang dianggap paling final apabila sebuah fatwa

Ulama Indonesia (MUI). Mengapa justru 
yang dijadikan pedoman justru keputusan dari MUI? Hal itu kembali pada mayoritas orang Indonesia yang selain faktor geografis yang berpengaruh terhadap terbentuknya opinion leader, faktor agama juga dapat berpengaruh. Islam menjadi agama mayoritas penduduk Indonesia.

Dalam ruang lingkup umat Islam, filter informasi akan kembali kepada organisasi yang menaunginya. Jadi pada kasus ini, opinion leader diduduki oleh pelaku komunikasi organisasi yang menyandang posisi mayoritas. Dari komunikasi organisasi yang dimaksud di atas sesungguhnya masih bisa diturunkan ke dalam kelas interpersonal yaitu berupa figur KH. Abdurrahman Wahid, Amin Rais, dan ulama- ulama lainnya.

Sebenarnya masih banyak contoh tentang adanya peran opinion leader dalam komunikasi, terlebih dalam SKI apalagi jika ditrunan dalam cakupan geografis yang lebih sempit. Garis besar dari teori Limited Effect adalah adanya tiga poros yaitu media massa, audience dan opinion leader.

Berhubung daerah- daerah di luar kota juga sedah terjamah oleh perkembangan teknologi dan informasi maka tidak menutup kemungkinan jika masyarakat sedah memliki pola konsumsi media massa, baik itu cetak maupun elektronik. Namun, pada prartiknya, apa yang disampaikan media kepada khalayak masyarakat pada saat sekarang juga tak sesempurna yang didambakan. Untuk hal- hal yang laten seperti agama dan kepercayaan, peran opinion leader sangat kental nuansanya sebagai pamong yang menetralisir arus informasi.

\section{Metode Penelitian}

Penelitian yang digunakan adalah penelitian deskriptif kualitatif. Menurut Poerwandari (1998) penelitian kualitatif adalah penelitian yang menghasilkan dan mengolah data yang sifatnya deskriptif, seperti transkripsi wawancara, catatan lapangan, gambar, foto rekaman video dan lain-lain. Dalam penelitian kualitatif perlu menekankan pada pentingnya kedekatan dengan orang-orang dan situasi penelitian, agar peneliti memperoleh pemahaman jelas tentang realitas dan kondisi kehidupan nyata. pendekatan kualitatif, yaitu penelitian yang menggunakan data pokok yang berbentuk kalimat, gambar, dan sebagainya. Dengan definisi tersebut, maka penelitian kualitatif deskriptif menjadi acuan peneliti untuk menghasilkan datadata baru

Metode penelitian yang digunakan dalam penelitian ini adalah metode deskriptif kualitatif yang berusaha memberikan gambaran sekaligus menerangkan fenomena-fenomena yang ada sebagai prosedur pemecahan masalah yang diselidiki dari keadaan yang adadi

berdasarkan fakta-fakta yang tampak atau 
sebagaimana mestinya sesuai dengan permasalahan penelitian. Berkaitan dengan judul penelitian, yang termasuk dalam gejala-gejala sosial yang ada bersifat deskiptif kualitatif, sehingga penelitian ini menggunakan jenis penelitian deskriptif kualitatif.

Penelitian dengan menggunakan metode kualitatif yang umunya berangkat dari pertanyaan why atau how. Untuk itu teknik penelitian yang digunakan peneliti dengan studi kasus, karena permasalahan yang diteliti lebih sesuai apabila menggunakan studi kasus. Bogdan dan Biklen (1982) menjelaskan studi kasus merupakan pengujian secara rinci terhadap satu latar atau satu subjek atau satu tempat penyimpanan dokumen atau satu peristiwa tertentu.

Metode ini digunakan karena:

a. Metode kualitatif lebih mudah menggambarkan keadaan dan menyesuaikan dengan keadaan yang sesungguhnya apabila berhadapan langsung dengan kehidupan nyata.

b. Metode ini juga lebih peka dan lebih dimengerti karena peneliti mempelajari fenomena yang terjadi dengan jalan mengumpulkan data berupa cerita rinci dari informan. c. Informasi detail karena sesuai dengan pandangan responden/informan.

Dalam penelitian ini, peneliti mengamati fenomena yang terjadi dan yang lebih difokuskan kembali ke area desa di wilayah Jember. Yaitu Desa Sukorambi. Peneliti terjun langsung dalam mengumpulkan data, dan tidak bisa dimanipulasi, karena fenomena yang terjadi memang benar - benar ada pada Desa Sukorambi-Jember.

Berdasarkan jenisnya, sumber data yang diperoleh berdasarkan hasil data tertulis karena bersifat naratif dan deskriptif. Jenis data tertulis teridiri atas hasil wawancara. Serta dari pihak luar (eksternal) meliputi informasi dari media massa yang berkaitan dengan judul (majalah, artikel, dan berita lain yang disiarkan melalui media massa).

Menurut McMillan \& Schumacher (2003) menjelaskan bahwa penelitian kualitatif tidak dimaksudkan untuk membuat generalisasi dari hasil penelitian yang dilakukan sehingga subjek penelitian yang telah tercermin dalam fokus penelitian ditentukan secara sengaja. Subjek penelitian inilah yang akan memberikan berbagai informasi dari informan yang diperlukan selama proses penelitian. 
Informan yang diteliti dalam penelitian ini terdapat beberapa informan yang terbagi menjadi dua, yaitu:

a. Informasi Kunci (KeyInformant)

Informasi Kunci (KeyInformant) yaitu informan yang memiliki berbagai pokok informasi yang diperlukan dalam penelitian atau informan yang memberi informasi secara mendalam dalam permasalahan yang diteliti. Informan kunci ini diantaranya dia yang menguasai atau memahami sesuatu yang menjadi pusat penelitian, sehingga sesuatu itu bukan sekedar diketahui tetapi juga dihayati. Dalam penelitian ini, yang menjadi key informant adalah Kepala Desa Sukorambi yang bernama Ahmad Halil.

b. Informan Kedua (second informant)

Informan Kedua (second informant) yaitu informan yang sama pentingnya dengan informan kunci, sama-sama memberikan informasi penting yang turut mendukung berhasilnya penelitian. Informan kedua membantu melengkapi berbagai informasi yang telah disampaikan informan kunci. Dalam penelitian ini yang berperan sebagai informan kedua adalah Bapak Kepala Dusun Manggis yang bernama Muhammad Sugik.

Berdasarkan uraian diatas, maka peneliti menentukan informan kunci dan informan kedua dengan menggunakan teknik Purposive Sampling yang merupakan teknik sampling dengan menentukan criteria yang tepat pada informannya. Teknik ini paling banyak dipakai ketika peneliti tidak banyak tahu tentang populasi penelitiannya. Dia hanya tahu satu atau dua orang yang berdasarkan penilaiannya bisa dijadikan sampel. Pengambilan sampel untuk suatu populasi dapat dilakukan dengan cara mencari contoh sampel dari populasi yang kita inginkan, kemudian dari sampel yang didapat dimintai partisipasinya untuk memilih komunitasnya sebagai sampel lagi, seterusnya hingga jumlah sampel yang diinginkan terpenuhi.

c. Informan Tambahan

Informan Tambahan/Pendukung yaitu informan yang mempunyai informasi tambahan, dan dapat melengkapi hasil data dari informan kunci. Informan tambahan ini berdasarkan rekomendasi dari informan kunci. Informan tambahan dari penelitian ini ada dua yang pertama adalah Ulama/Bindereh yang bernama Kiai Hartatik. Informan tambahan yang kedua adalah Penerima Program "Bedah Rumah" yang bernama Bapak Tohar.

Dalam memperoleh data dan informasi, peneliti menggunakan metode pengumpulan data primer dan sekunder yang terdiri sebagai berikut:

a. Pengumpulan Data Primer

1. Wawancara (interview)

Teknik wawancara dalam Moelong (2005), merupakan teknik pengumpulan 
data kualitatif dengan menggunakan instrument yaitu berupa pedoman wawancara. Peneliti menggunakan teknik wawancara dengan mewawancari langsung informan/narasumber dengan berdasarkan masalah yang akan diteliti.

Pertama peneliti membuat pedoman wawancara yang disusun berdasarkan demensi perjalanan dalam memilih mengenakan hijab sesuai dengan permasalahan yang dihadapi subjek. Pedoman wawancara ini berisi pertanyaanpertanyaan mendasar yang nantinya akan berkembang dalam wawancara. Pedoman wawancara yang telah disusun, ditunjukan kepada yang lebih ahli dalam hal ini adalah pembimbing penelitian untuk mendapat masukan mengenai isi pedoman wawancarara. Setelah mendapat masukan dan koreksi dari pembimbing, peneliti membuat perbaikan terhadap pedoman wawancara dan mempersiapkan diri untuk melakukan wawancara. Tahap persiapan selanjutnya adalah peneliti membuat pedoman observasi yang disusun berdasarkan hasil observasi terhadap perilaku subjek selama wawancara dan observasi terhadap lingkungan atau setting wawancara, serta pengaruhnya terhadap perilaku subjek dan pencatatan langsung yang dilakukan pada saat peneliti melakukan observasi. Namun apabila tidak memungkinkan maka peneliti sesegera mungkin mencatatnya setelah wawancara selesai.

Peneliti selanjutnya memilih subjek yang sesuai dengan karakteristik subjek penelitian. Untuk itu sebelum wawancara dilaksanakan, peneliti bertanya kepada subjek tentang kesiapanya untuk diwawancarai. Setelah subjek bersedia untuk diwawancarai, peneliti membuat kesepakatan dengan subjek tersebut mengenai waktu dan tempat untuk melakukan wawancara.

Wawancara dilakukan menggunakan pedoman wawancara yang telah tersusun secara sistematis diatas.

\section{Observasi}

Disamping wawancara, penelitian ini juga melakukan metode observasi. Menurut Nawawi \& Martini (1991) observasi adalah pengamatan dan pencatatan secara sistematik terhadap unsur-unsur yang tampak dalam suatu gejala atau gejala-gejala dalam objek penelitian.

Dalam penelitian ini observasi dibutuhkan untuk dapat memahami proses terjadinya wawancara dan hasil wawancara dapat dipahami dalam konteksnya. Observasi yang akan dilakukan adalah observasi terhadap subjek, perilaku subjek selama wawancara, interaksi subjek dengan peneliti dan hal-hal yang dianggap relevan sehingga dapat memberikan data tambahan terhadap hasil wawancara. 
Menurut Patton dalam (Poerwandari, 1998) tujuan observasi adalah mendeskripsikan setting yang dipelajari, aktivitas-aktivitas yang berlangsung, orangorang yang terlibat dalam aktivitas, dan makna kejadian di lihat dari perpektif mereka yang terlihat dalam kejadian yang diamati tersebut.

Menurut Patton dalam (Poerwandari, 1998) salah satu hal yang penting, namun sering dilupakan dalam observasi adalah mengamati hal yang tidak terjadi. Dengan demikian Patton menyatakan bahwa hasil observasi menjadi data penting karena:

a. Peneliti akan mendapatkan pemahaman lebih baik tentang konteks dalam hal yang diteliti akan atau terjadi.

b. Observasi memungkinkan peneliti untuk bersikap terbuka, berorientasi pada penemuan dari pada pembuktiaan dan mempertahankan pilihan untuk mendekati masalah secara induktif.

c. Observasi memungkinkan peneliti melihat hal-hal yang oleh subjek penelitian sendiri kurang disadari.

d. Observasi memungkinkan peneliti memperoleh data tentang hal-hal yang karena berbagai sebab tidak diungkapkan oleh subjek penelitian secara terbuka dalam wawancara.

e. Observasi memungkinkan peneliti merefleksikan dan bersikap introspektif terhadap penelitian yang dilakukan. Impresi dan perasan pengamatan akan menjadi bagian dari data yang pada giliranya dapat dimanfaatkan untuk memahami fenomena yang diteliti.

f. Teknik pengumpulan data dengan menggunakan dokumentasi mendukung untuk kelengkapan data dalam proses penelitian. Dokumnetasi adalah teknik kedua dan terakhir dalam pengumpulan data yang bersifat tercetak. Teknik ini bertujuan untuk melengkapi data-data tambahan serta mendukung berhasilnya penelitian seperti, buku-buku, artikel, ataupun berita yang terkait.

Sedang Pengumpulan Data Sekunder

1. Studi Dokumentasi

Teknik pengumpulan data dengan menggunakan catatan atau dokumen yang ada di lokasi penelitian atau sumber- 
sumber lain yang terkait dengan objek penelitian (Bungin, 2007).

Studi dokumentasi dalam penelitian ini dilakukan dengan mengumpulkan datadata sekunder yang terkait dengan permasalahan penelitian. Data-data sekunder disini berhubungan dengan gambaran umum para karyawan Radio Prosalina Fm, dan dalam kegiatan wawancara dengan subjek peneliti.

\section{Studi Pustaka}

Teknik pengumpulan data dengan menggunakan studi pustaka untuk mendukung kelengkapan data dalam proses penelitian. Studi pustaka adalah teknik terakhir yang di pakai oleh peneliti untuk mengumpulkan berbagai sumber informasi sehingga data-data yang dibutuhkan lengkap. Studi pustaka bersifat tercetak (printed) seperti buku-buku dan tulisantulisan. Peneliti mendapatakan mulai dari artikel hingga karya ilmiah yang berkaitan dengan tema dan judul yang diambil.

Teknik analisis data dalam penelitian ini menggunakan pendekatan kualitatif yang dapat berupa kata-kata, kalimat, atau narasi, baik yang diperoleh dari hasil wawancara maupun observasi. Data yang diperoleh dari hasil penelitian ini disusun dan di analisis dengan menggunakan teknik analisis deskriptif.

Bogdan dan Sugiyono menjelaskan, analisis data adalah proses mencari dan c. mayoritas penduduknya etnis menyusun secara sistematis data yang diperoleh dari hasil wawancara, catatan lapangan, dan bahan-bahan lain, sehingga dapat mudah difahami dan temuannya dapat diinformasikan kepada orang lain.

Penyajiannya dapat dilakukan dalam bentuk uraian singkat, bagan, hubungan antar kategori, flowcart, dan sejenisnya. Peneliti menganalisa data ke dalam beberapa tahap antara lain:

a. Mengumpulkan data dan informasi sebanyak-banyaknya.

b. Data-data yang di dapat kemudian disusun berdasarkan rumusan masalah dan tujuan.

c. Data yang telah dikumpulkan dan di susun kemudian diinterpretasikan.

d. Berdasarkan analisa dan penafsiran yang dibuat, ditarik kesimpulan serta saran untuk kebijakan.

Penelitian ini akan dilaksanakan pada Desa Sukorambi Kabupaten Jember. Pemilihan lokasi objek penelitian ini didasarkan pada pertimbangan bahwa terdapat program "Bedah Rumah" dari pemerintah pusat. Alasan penulis dalam memilih lokasi Desa Sukorambi karena Desa Sukorambi-Jember adalah diantaranya:

a. Desa Sukorambi adalah salah satu penerima program "Bedah Rumah" dari Program Pemerintah

b. Desa Sukorambi adalah desa yang Madura, dimana masyarakat masih 
memposisikan beberapa orang menjadi pemuka pendapat dalam menyelesaikan masalah sosial maupun pemerintahan.

\section{Pembahasan}

\section{Gambaran Umum Sukorambi - Jember}

Kabupaten Jember adalah kabupaten di ProvinsiJawa Timur, Indonesia yang beribukota di Jember. Kabupaten ini berbatasan dengan Kabupaten Probolinggo dan Kabupaten Bondowoso di utara, Kabupaten Banyuwangi di timur, Samudra Hindia di selatan, dan Kabupaten Lumajang di barat. Kabupaten Jember terdiri dari 31 kecamatan. Jember dahulu merupakan kota administratif, namun sejak tahun 2001 istilah kota administratif dihapus, sehingga Kota Administratif Jember kembali menjadi bagian dari Kabupaten Jember. Jember merupakan pusat regional di kawasan timur tapal kuda. Hari jadi Kabupaten Jember diperingati setiap tanggal 1 Januari.

Kabupaten Jember dibentuk berdasarkan Staatsblad Nomor 322 tanggal 9 Agustus 1928 dan sebagai dasar hukum mulai berlaku tanggal 1 Januari 1929. Pemerintah Hindia Belanda telah mengeluarkan ketentuan tentang penataan kembali pemerintah desentralisasi di wilayah Provinsi Jawa Timur, antara lain dengan menunjuk Regenschap Djember Berdasarkan Undang Undang No. sebagai masyarakat kesatuan hukum yang berdiri sendiri. Secara resmi ketentuan tersebut diterbitkan oleh Sekretaris Umum Pemerintah Hindia Belanda (De Aglemeene Secretaris) G.R. Erdbrink, 21 Agustus 1928.

Pemerintah Regenschap Jember yang semula terbagi dalam tujuh Wilayah Distrik, pada tanggal 1 Januari 1929 sejak berlakunya Staatsblad No. 46/1941 tanggal 1 Maret 1941 Wilayah Distrik dipecah menjadi 25 Onderdistrik, yaitu:

i. Distrik Jember, meliputi onderdistrik Jember, Wirolegi, dan Arjasa.

ii. Distrik Kalisat, meliputi onderdistrik Kalisat, Ledokombo, Sumberjambe, dan Sukowono.

iii. Distrik Rambipuji, meliputi onderdistrik Rambipuji, Panti, Mangli, dan Jenggawah.

iv. Distrik Mayang, meliputi onderdistrik Mayang, Silo, Mumbulsari, dan Tempurejo.

v. Distrik Tanggul meliputi onderdistrik Tanggul, Sumberbaru, dan Bangsalsari.

vi. Distrik Puger, meliputi onderdistrik Puger, Kencong Gumukmas, dan Umbulsari.

vii. Distrik Wuluhan, meliputi onderdistrik Wuluhan, Ambulu, dan Balung.

12/1950 tentang Pemerintah Daerah 
Kabupaten di Jawa Timur, ditetapkan pembentukan Daerah-daerah Kabupaten dalam lingkungan Provinsi Jawa Timur (dengan Perda), antara lain Daerah Kabupaten Jember ditetapkan menjadi Kabupaten Jember.

Dengan dasar Peraturan Pemerintah Nomor 14 Tahun 1976 tanggal 19 April 1976, dibentuklah Wilayah Kota Jember dengan penataan wilayah-wilayah baru sebagai berikut:

i. Kacamatan Jember dihapus, dan dibentuk tiga kecamatan baru, masing-masing Sumbersari, Patrang dan Kaliwates.

ii. Kecamatan Wirolegi menjadi Kecamatan Pakusari dan Kecamatan Mangli menjadi Kecamatan Sukorambi.

Bersamaan dengan pembentukan Kota Administratif Jember, wilayah Kewedanan Jember bergeser pula dari Jember ke Arjasa dengan wilayah kerja meliputi Arjasa, Pakusari, dan Sukowono yang sebelumnya masuk Distrik Kalisat. Dengan adanya perubahan-perubahan tersebut, pada perkembangan berikutnya, secara administratif Kabupaten Jember saat itu terbagi menjadi tujuh Wilayah Pembantu Bupati, satu wilayah Kota Administratif, dan 31 Kecamatan.

Dengan diberlakukannya Otonomi Daerah sejak 1 Januari 2001 sebagai merupakan bagian dari rangkaian Dataran tuntutan No 22/1999 tentang Pemerintahan Daerah, Pemerintah Kabupaten Jember telah melakukan penataan kelembagaan dan struktur organisasi, termasuk penghapusan lembaga Pembantu Bupati yang kini menjadi Kantor Koordinasi Camat. Selanjutnya, dalam menjalankan roda pemerintah di era Otonomi Daerah ini Pemerintah Kabupaten Jember dibantu empat Kantor Koordinasi Camat, yakni:

i. Kantor Koordinasi Camat Jember Barat di Tanggul

ii. Kantor Koordinasi Camat Jember Selatan di Balung

iii. Kantor Koordinasi Camat Jember Tengah di Rambipuji

iv. Kantor Koordinasi Camat Jember Timur di Kalisat

Jember memiliki luas $3.293,34 \mathrm{Km}^{2}$ dengan ketinggian antara $0-3.330 \mathrm{mdpl}$. Iklim Kabupaten Jember adalah tropis dengan kisaran suhu antara $23^{\circ} \mathrm{C}-32^{\circ} \mathrm{C}$. Bagian selatan wilayah Kabupaten Jember adalah dataran rendah dengan titik terluarnya adalah Pulau Barong. Pada kawasan ini terdapat Taman Nasional Meru Betiri yang berbatasan dengan wilayah administratif Kabupaten Banyuwangi. Bagian barat laut (berbatasan dengan Kabupaten Probolinggo adalah pegunungan, bagian dari Pegunungan Iyang, dengan puncaknya Gunung Argopuro (3.088 m). Bagian timur Tinggi Ijen. Jember memiliki beberapa 
sungai antara lain Sungai Bedadung yang bersumber dari Pegunungan Iyang di bagian Tengah, Sungai Mayang yang persumber dari Pegunungan Raung di bagian timur, dan Sungai Bondoyudo yang bersumber dari Pegunungan Semeru di bagian barat.

Desa Sukorambi mempunyai batas wilayah:

Utara : Gunung Argopuro

Timur : Desa karangpring

Selatan : Desa Dukuh mencek

Barat : Desa Suci dan Desa Serut.

Desa Sukorambi memiliki luas wilayah 774.295 Ha, dari segi topografi, desa Sukorambiberada pada bagian utara wilayah kabupaten jember yang merupakan daerah pertanian yang subur untuk pengembangan tanaman pangan.

Tabel 4.1 Luas Wilayah Desa

Sukorambi-Jember Berdasarkan

Pemanfaatannya Tahun 2014

\begin{tabular}{|c|l|l|}
\hline No & Luasan Wilayah & Luas (Ha) \\
\hline$\cdot$ & & \\
\hline 1 & Pemukiman Penduduk & 280 \\
2 & Perkebunan/persawahan & 570 \\
3. & Perkantoran & 17 \\
4. & Sekolah & 26 \\
\hline \multicolumn{2}{|l}{} & 1180 ha \\
\hline
\end{tabular}

Sumber Data : Kantor Desa

Sukorambi-Jember, 2014

Tabel 4.1 menunjukkan luas wilayah desa Tanggul Kulon-Jember yang telah dimanfaatkan meliputi pemukiman penduduk seluas 280 ha, areal perkebunan atau persawahan yang dikelola masyarakat, luasnya mencapai 570 ha dan sebagian besar ditanaman dengan pohon kelapa. Areal untuk perkantoran 17 ha dan sekolah 26 ha. Dari luas wilayah tersebut di atas terbagi menjadi bebarapa kawasan : diantaranya kawasan irigasi teknis, dataran tinggi dan dataran rendah.

Desa Sukorambi dikenal sebagai desa agraris. Memiliki potensi alam yang cukup prospektif bagi pengembangan perekonomian wilayah ditingkat Desa. Sesuai dengan potensi ekonomi desa yang ada, perekonomian di Desa Sukorambi masih mengandalkan pada sector pertanian sebagai basis dan penggerak roda perekonomian di wilayah. Pertanian sebagai sector unggulan sampai saat ini masih memeliki perang yang dominant dan strategis bagi pembangunan perekonomian baik sebagai penyedia bahan pangan bahanbakuproduk olahan, peningkatan pendapatan desa dan masyarakat serta penyerapan tenaga kerja dalam jumlah signifikan .

Sumber daya yang ada saat ini yang menjadi potensi ekonomi yang unggul adalah di bidang pertanian dengan bebarapa produk yang di hasilkan meliputi :, Padi, jagung, Kedelai , Ubi , kacang 
Panjang, Kacang tanah, sayur mayor, Rambutan dan tanaman palawija lainnya.

Secara umum mata pencaharian Penduduk desa Sukorambi dapat diklasifikasikan dalam beberapa bidang yaitu sesuai dengan table sebagai berikut :

Table 4.2 Mata Pencaharian Penduduk Sukorambi

\begin{tabular}{|c|l|l|}
\hline 1 & Pertanian & 3.908 jiwa \\
\hline 2 & Industri pengolahan & 1832 jiwa \\
\hline 3 & Konstruksi / bangunan & 201 jiwa \\
\hline 4 & Dan Lain - lain & 50 jiwa \\
\hline
\end{tabular}

Sumber : Kantor Desa Sukorambi 2014

Berdasarkan hasil registrasi penduduk sampai dengan tahun 2014 penduduk Desa Sukorambi.-Jember berjumlah 11.347 jiwa. Jiwa penduduk lakilaki dan 5.972 jiwa penduduk perempuan yang terdiri dari 5.625 jiwa. Struktur umur penduduk sebagian besar penduduknya masih tergolong usia produktif karena mereka merupakan penduduk yang aktif bekerja pada bidangnya masing-masing untuk memperoleh tingkat pendapatan.

Lokasi penelitian mempunyai perubahan iklim yang sama dengan daerahdaerah lainnya di Kabupaten Jember, khususnya di Kecamatan Sukorambi. Berdasarkan data yang diperoleh, Desa Sukorambi-Jember beriklim tropis yang pada umumnya sama dengan di daerah lain yang ada di Kecamatan Sukorambi Kabupaten Jember, yang beriklim tropis dengan peluang musim hujan selama 7 bulan dan musim kemarau selama 5 bulan, sedangkan curah hujan dalam kurun waktu 5 tahun terakhir rata-rata adalah $173 \mathrm{~mm}$ perbulan. Keadaan iklim kadangkala berubah-ubah tapi sesuai kondisi di Desa Sukorambi -Jember pada umumnya sama dengan di daerah lain yang ada di Kabupaten Jember yaitu pada bulan Oktober sampai bulan Maret berlangsung musim kemarau dan dari bulan April sampai dengan bulan September berlangsung musim penghujan. Namun demikian, kondisi iklim tersebut ada kalanya tidak menentu, tetapi sesuai tipe iklim yang dimiliki pada Desa Sukorambi Jember peluang musim penghujan lebih besar ketimbang musim kemarau dalam setiap tahunnya

\section{Pemuka Pendapat Sukorambi-Jember}

Opinion leader adalah orang yang mempunyai keunggulan dari masyarakat kebanyakan. Seorang opinion leader mempunyai karakteristik yang membedakan dirinya dengan orang lain. Beberapa karakteristik yang dimaksud adalah : lebih tinggi status soaialekonominya, lebih inovatif dalam menerima dan mengadopsi ide baru, lebih tinggi pengenalan medianya (media exposure), kemampian empatinya lebih besar, partisipasi sosial lebih besar (Nurudin dalam Sistem Komunikasi 
Indonesia).

Salah satu keunggulan opinion leader dibanding dengan masyarakat kebanyakan adalah pada umumnya opinion leader itu lebih mudah menyesuaikan diri dengan masyarakatnya, lebih kompeten dan lebih tahu memelihara norma yang ada. Kemampuan dirinya memelihara norma menjadi salah satu konsekuensi logis bentuk pelayanan atau suri teladan yang diberikan atau ditunjukkan kepada masyarakatnya. Menurut Homans (1961), "Seorang yang memiliki status sosial tinggi akan senantiasa memelihara nilai-nilai serta norma kelompoknya sebagai syarat minimal dalam mempertahankan statusnya" (Deparin dan Andrew, 1982). Pada diri seorang pemimpin opini bisa jadi hanya melekat beberapa ciri saja. Namun, karena kemampuannya menjaga kredibilitas (karena wibawa atau wewenang) ia ditokohkan oleh masyarakatnya. Yang jelas dalam berbagai hal ia lebih unggul dengan yang lainnya.

Tak bisa dipungkiri bahwa opinion leader menjadi salah satu unsur yang sangat mempengaruhi proses komunikasi, khususnya di pedesaan. Hal ini karena Desa merupakan tempat hidup masyarakat tradisional yang masih memiliki cara hidup, cara berperilaku dan cara berinteraksi yang bersifat tardisional pula. Pola hidup yang saling membantu dengan menjunjung tinggi nilai-nilai dan norma-norma kebersamaan adalah cerminan hidup yang selalu dipegang teguh oleh masyarakat pedesaan. Berbagai perubahan dan kemajuan masyarakat sangat ditentukan oleh peran opinionleader ini. Misalnya, memotivasi masyarakat agar ikut serta secara aktif dalam pembangunan dan kegiatan-kegiatan masyarakat lainnya.

Adapun beberapa ciri opinion leader beserta proses komunikasi yang dijalankan adalah sebagai berikut:

1. Komunikasi interpersonal mempunyai struktur jaringan yang telah tertentu (umpamanya, kerabat, keluarga besar, suku, dan sebagainya) yang sangat kuat, karena ikatan yang telah lama ada, kebiasaan-kebiasaan setempat yang telah lama tertanam, dan setiap struktur ini mempunyai pemukapemuka pendapatnya.

2. Komunikasi di dalam masyarakat Indonesia ditandai oleh ciri-ciri sistem komunikasi feodal. Ada garis hirarki yang ketat sebagai bawaan dari sisten tradisional; pemukapemuka pendapat sudah tertentu dan mempunyai pengaruh yang jelas sementara arus komunikasi cenderung berjalan satu arah.

3. Pemuka-pemuka pendapat ini dianggap telah dikenali dan dapat diketahui dengan mudah dari 
fungsi mereka masing-masing dalam pranata-pranata informal yang telah berakar dalam masyarakat.

4. Pemuka-pemuka pendapat tidak hanya mereka yang memegang fungsi dalam pranata informal masyarakat tetapi juga pemimpin formal, termasuk yang menempati kedudukan karena ditunjuk dari luar.

5. Pemuka pendapat di Indonesia dianggap bersifat polimorfik, yaitu serba tahu atau tempat menanyakan segalah rupa hal. Adanya asumsi ini terlihat dari kecenderungan untuk menyalurkan segala macam informasi kepada para pemika yang sama. (Nurudin dalam Sistem Komunikasi Indonesia)

Berdasarkan lokasi penelitian, di dalam penelitian ini pemuka pendapat yaitu, tokoh masyarakat dan bindereh(semacam tokoh masyarakat pemuka agama dalam bahasa Madura). Berdasar fenomena dan realita yang terjadi dalam proses interaksi antara opinion leader dan masyarakat, maka dalam pola interaksi yang terjadi antara Bindereh (masyarakat setempat menyebut opinion leader dengan kata Bindereh) dan masyarakat, serta pemakaian lambang komunikasi oleh Bindereh dalam rangka menyebarkan informasi, pesan, nasihat, perintah, amanah ataupun arahan kepada masyarakat kita.

Istilah opinion leader menjadi perbincangan dalam literatur komunikasi sekitar tahun 1950-1960-an sebelumnya literatur komunikais sering digunakan katakata influentials, influencers atau tastemakers untuk menyebut opinion leader. Kemudian kata opinion leader lebih sering dikenal dimasyarakat pedesaan, sebab pada saat itu tingkat media masih rendah serta pendidikan yang belum maju. Jadi kebutuhan akan informasi dipedesaan diterima dari mereka yang mempunyai pemahaman yang tinggi serta kebutuhan akan media yang tidak rendah.

Ada dua pengelompokan opinion leader menurut Wilcox (2001):

c. Opinion Leader Aktif (Opinion Giving)

Disini para opinion leader tersebut sengaja mencari penerima atau followers untuk mengumumkan atau mensosialisasikan suatu informasi. Contoh : saat adanya program bedah rumah yang bertujuan membantu masyarakat yang benar-benar membutuhkan bantuan dalam menciptakan kondisi rumah yang sehat. Tapi bagi masyarakat desa hal ini masih terlalu baru dan mereka belum mengenal apa itu Bedah Rumah sebenarnya, maka disini peranan opinion leader tersebut dituntun untuk menyampaikan informasi bahwa program ini bertujuan penting bagi 
kelangsungan masyarakat dipedesaan.

\section{d. Opinion Leader Pasif (Opinion Seeking)}

Dalam hal ini followers lebih aktif mencari sumber informasinya kepada opinion leader, sehubungan dengan permasalahan yang dihadapi seperti halnya contoh diatas tersebut.

Di dalam penelitian ini, pemuka pendapat yaitu tokoh masyarakat dan juga bindereh, lebih sebagai Opinion Leader Pasif (Opinion Seeking). Hal ini dikarenakan menjadi program pemerintah setempat yang menjadi ranah kewenangan pemerintah, pemuka pendapat mendapat posisi pasif dalam hal ini.

\section{Pembahasan}

\section{Peran Pemuka Pendapat Sukorambi-} Jember dalam program "Bedah Rumah" di Desa Sukorambi

Program bedah rumah merupakan sebuah program rehabilitasi rumah yang tidak layak huni dan tidak sehat menjadi rumah yang sehat serta layak huni. Pemberdayaan masyarakat menunjukkan pada kemampuan orang khususnya kelompok entan atau lemah sehingga memiliki kekuatan atau kekuatan dalam:

a. Memenuhi kebutuhannya sehingga mereka memiliki kebebasan, bukan saja bebas mengeluarkan pendapat tetapi bebas dari kelaparan, kebodohan dan penyakit. b. Menjangkau sumbersumber produktif yang memungkinkan mereka untuk meningkatkan pendapatannya dan memperoleh barang-barang dan jasa yang mereka butuhkan.

c. Berpartisipasi dalam proses pembangunan dan keputusan-keputusan yang mempengaruhi mereka (Suharto:2003)

Bedah Rumah adalah program pemerintah dari Kementerian Perumahan Rakyat (Kemenpera) tengah menjajaki kerjasama dengan Dewan Perwakilan Daerah (DPD) untuk pelaksanaan program bedah rumah di daerah-daerah. Keterlibatan DPD membantu Kemenpera dalam menyerap aspirasi masyarakat di daerah, terkait penyaluran bantuan perumahan swadaya melalui program bedah rumah. Program ini bertujuan untuk mengentaskan kemiskinan dan membantu warga Negara yang kurang mampu untuk memiliki rumah layak huni.

Untuk mengetahui pelaksanaan kegiatan bedah rumah di Sukorambi Jember peneliti melakukan wawancara dengan beberapa narasumber salah satunya Kepala Desa Sukorambi Jember (Ahmad 
Halil) sesuai hasil wawancara tanggal 7

Mei 2015 sebagai berikut :

"Kegiatan bedah rumah yang diprogramkan pemerintah ini disambut baik oleh seluruh elemen masyarakat dalam membantu masyarakat miskin disekitarnya untuk memenuhi kebutuhan akan rumah yang layak huni”.

Hal ini sesuai dengan wawancara dengan Kepala Dusun Manggis (Mohammad Sugik) tanggal 7 Mei 2015sebagai berikut:

"Pelaksanaan kegiatan ini dilakukan dengan melibatkan seluruh lapisan masyarakat sesuai dengan kemampuan dan fungsinya masing-masing, orang buta dan orang lumpuhpun sekalipun harus dilibatkan dalam pelaksanaan ini walaupun itu hanya berupa doanya saja".

Dari hasil wawancara dengan para narasumber tersebut dapat diketahui bahwa kegiatan bedah rumah ini sangat didukung oleh budaya lokal setempat seperti rasa kekerabatan yang masih tinggi karena mereka merasa menjadi bagian dari keluarga penerima bantuan serta merasa diperlukan oleh kelompoknya. Mereka bersama-sama menolong saudaranya yang tidak mampu untuk memenuhi kebutuhan rumah yang layak huni, karena masalah seberat apapun kalau diselesaikan secara bersama-sama akan terasa ringan.

Selain dari kriteria rumah tidak layak huni yang telah ditetapkan oleh
Pemkab Agam, kriteria lainnya pemilihan penerima bantuan di Sukorambi Jember berdasarkan program penanggulangan kemiskinan berbasiskan mesjid yang melihat aspek kemiskinan dari berbagai aspek yaitu : aspek umum, aspek perumahan, aspek pendidikan, aspek kesehatan, aspek ekonomi, dan aspek keagamaan. Dari hasil wawancara dengan salah satu narasumber (Febrianto, $\mathrm{SH}$ ) Sekretris Tim Koordinasi Penaggulangan Kemiskinan dapat diperoleh pernyataan sebagai berikut :

"Aspek tersebut diatas digunakan untuk menentukan tingkat kemiskinan seseorang, dan yang mendapat prioritas adalah keluarga yang mempunyai skor paling besar. Dalam pemilihan rumah warga yang akan dibedah selalu melibatkan seluruh unsur masyarakat terutama kaum lansia, Perangkat Desa melakukan survey dan mendapatkan beberapa unit rumah tangga miskin yang diprioritaskan untuk dibedah, dimusyawarahkan dengan pemuka masyarakat, selanjutnya dipilih satu unit rumah yang akan dibedah dengan berbagai pertimbangan agar kegiatan ini berjalan dengan lancar”.

Dari hasil wawancara tersebut dapat diambil kesimpulan bahwa peran musyawarahlah lebih menentukan dalam pemilihan penerima bantuan, dalam musyawarah tersebut dipertimbangkan dampak yang akan terjadi pada 
pelaksanaan nantinya secara bersama. Hasil dari musyawarah tersebut sudah menjadi kesepakatan bersama, sehingga dalam proses kegiatan ini selanjutnya akan menjadi tanggung jawab bersama juga.

Untuk mengetahui kebiasaan masyarakat setempat dalam pelaksanaan pembangunan rumah maka peneliti berusaha menggali informasi dari salah satu narasumber, yaitu Kiai Hartatik (Bindereh) sesuai hasil wawancara dengan peneliti pada tanggal 7 Mei 2015 sebagai berikut :

"Program ini sangat kami dukung selaku pemuka agama di desa ini, jadi ya apapun tugas perangkat desa kami siap bantu sesuai dengan syariah Islam."

a) Peran Kyai / Bindereh :

Para ulama atau Kiai tidak hanya memiliki peran penting saat merebut kemerdekaan Indonesia dari tangan penjajah, namun di era modern ini ulama masih sangat berperan dalam tata kehidupan negara. Bahkan, dari pesantren, para ulama ini diharapkan tetap menjadi pengayom masyarakat agar tetap bersatu.

"Karena tidak ada ulama yang mengajarkan perilaku anarkhis kepada siapa pun, dan tidak mengajarkan pula perilaku bermusuh-musuhan. Para kiai tetap mengajarkan perilaku baik kepada sesama manusia serta lingkungannya,terutama saat program bedah rumah sukorambi ini". kata Kepala
Desa Sukorambi , Ahmad Halil. Minggu (20/5/2015).

Pernyataan tersebut disampaikan disela-sela menghadiri peresmian bedah rumah di Sukorambi.. Halil pada acara itu para perangkat desa yang juga ingin bersama member kesempatan kyai hartatik untuk menjadi pemuka agama di dalam program bedah rumah, khususnya warga sukorambi sendiri. Hal ini dilakukan setiap tahun. Diharapkan, kegiatan ini bermanfaat bagi kaum muslim,. Menurut Halil, peran penting ulama atau kiai pada era modern ini mereka mengajarkan kebaikan bersendikan agama, sehingga tidak mengajarkan tindakan anarkhis. Bahkan, kebijakan kiai harus bermanfaat langsung kepada para santrinya.

"Karenanya, para santri yang tengah belajar di pesantren merupakan harapan menjadi pemimpin yang baik di masa depan," paparnya.

Dia juga menjelaskan, karena peran (doa) para ulama ini pula sampai saat ini negara Indonesia tidak mengalami krisis politik dan ekonomi. Padahal negara dibelahan dunia lainnya mengalaminya.

b) Peran Perangkat Desa dalam bedah rumah

Berdasarkan temuan penelitian dijelaskan bahwa, secara umum Aparatur Pemerintah Desa merupakan alat penyelenggara pemerintahan di desa. Sebagai 
penyelenggara pemerintahan di desa maka aparatur pemerintah Desa memiliki tugas dan fungsi pokok dalam meningkatkan mutu pelayanan publik. Tugas pokok

Aparatur Pemerintah Desa dalam upaya meningkatkan mutu pelayanan publik di Desa Sukorambi.

Saat ini telah terjadi pergeseran paradigma dunia dalam pembangunan ke arah yang lebih menekankan pembangunan manusia sebagai dasar bagi pertumbuhan ekonomi yang berkelanjutan serta peningkatan dan pemerataan kesejahteraan masyarakat. Pembangunan manusia telah menjadi arah utama dalam praktik penyelenggaraan pemerintahan yang sebagian tujuannya telah dirumuskan dalam Millenium Development Goals (MDG's) yaitu pengurangan jumlah penduduk miskin melalui pembangunan yang berorientasi pada pemenuhan hak-hak dasar manusia.

Kemiskinan kini tidak lagi dianggap sebagai permasalahan ekonomi semata, tetapi lebih didefinisikan sebagai suatu kondisi dimana hak-hak dasar masyarakat untuk mempertahankan dan mengembangkan kehidupan yang bermartabat tidak dapat terpenuhi dengan baik. Hak dasar masyarakat yang diakui secara umum antara lain terpenuhinya kebutuhan pangan, sandang, dan papan/perumahan, akses kesehatan, akses pendidikan, air bersih, keberlanjutan lingkungan hidup, rasa aman, dan hak untuk berpartisipasi dalam kehidupan sosial-politik. Dalam kenyataanya hak-hak dasar tersebut tidaklah berdiri sendiri dan saling mempengaruhi satu sama lain, sehingga tidak terpenuhinya satu hak dapat mempengaruhi pemenuhan hak lainnya. Dalam konteks pembangunan manusia, pendayagunaan dan pengembangan local wisdom/kearifan lokal sebagai social capital seperti sifat kegotongroyongan dan keswadayaan masyarakat semestinya menjadi bagian penting dan tak terpisahkan dalam upaya pemenuhan atas hak dasar dan peningkatan kualitas hidup masyarakat. "Peran perangkat desa ya banyak sekali bagi kami warganya mas. Bisa dibilang kalo ndak ada perangkat desa, ndak kira kami rumahnya bias sampe dibenahi begini ini mas. Penting sekali dan besar sekali jasa mereka mas.Terutama pak tinggi nya (sebutan untuk kepala desa-dalam bahasa Madura)" (wawancara dengan warga,Sobari, 20 Mei 2015).

Permasalahan yang ada dalam proses pembangunan meliputi permasalahan yang sifatnya mendasar seperti yang umum dialami oleh sebagian besar daerah lain, serta permasalahan ikutan yang berkembang seiring dengan derap laju pembangunan. Berbagai permasalahan tersebut antara lain : belum 
terpenuhinya kebutuhan dasar masyarakat akan pangan, sandang, papan; tingginya angka pengangguran dan kemiskinan; laju pertumbuhan ekonomi yang masih lambat; terbatasnya sumber pembiayaan pembangunan daerah; dan terbatasnya kualitas sumberdaya manusia termasuk perilakunya sehingga belum mampu mewujudkan suatu penyelenggaraan pemerintahan yang berdasarkan pada prinsip-prinsip goodgovernance.

Program bedah rumah yang dirancang untuk membantu masyarakat miskin dalam pemenuhan rumah layak huni telah terlaksana sesuai tahun anggaran. Namun dalam pelaksanaannya banyak hal yang telah menyimpang dari tujuan awal seperti; kualitas bahan di bawah standar, terlambatnya waktu dari rencana awal, tenaga kerja yang tidak sesuai harapan, tidak tepat sasaran, dan berbagai masalah lain yang menjadi keluhan penerima bantuan. Perlu kajian dan evaluasi dari pelaksanaan program bedah rumah secara menyeluruh untuk meminimalkan masalah dalam pelaksanaannya dengan lebih mengedepankan swadaya masyarakat.

Program nasional perumahan rakyat pelaksanaanya masih sangat terbatas, bahkan belum menyentuh/menjangkau pembangunan dan rehabilitasi rumah tinggal keluarga miskin yang tidak layak huni di pedesaan. Hasil survei menunjukkan masih banyak rumah warga miskin di pedesaan yang tidak layak huni/tidak sehat (hasil survei tahun 2011 sebanyak 12.912 KK penduduk Jember yang memiliki rumah tidak layak huni). Rumah warga miskin yang tidak layak huni sangat mempengaruhi rendahnya derajat kesehatan, pendidikan dan ekonomi masyarakat. Keluarga miskin tidak memiliki kemampuan untuk melakukan rehabilitasi/perbaikan atas rumah tinggalnya yang tidak layak. Kebutuhan rumah layak huni dan sehat bagi warga miskin merupakan kebutuhan sosial dasar masyarakat yang harus dilaksanakan pemenuhannya.

Ada beberapa tujuan yang ingin dicapai dari pelaksanaan program bedah rumah. Pertama, percepatan upaya penaggulangan kemiskinan melalui peningkatan swadaya, prakarsa, dan peran serta masyarakat dalam pembangunan.

Kedua, peningkatan kapasitas penduduk miskin. Ketiga, pengembangan nilai budaya kegotongroyongan dan keswadayaan masyarakat. Keempat, terpenuhinya kebutuhan papan/perumahan yang layak huni dan sehat bagi masyarakat miskin. kelima, meningkatnya derajat kesehatan masyarakat melalui pembudayaan perilaku hidup bersih dan sehat.

Kontribusi Masyarakat 
Partisipasi dan swadaya masyarakat setiap desa/kelurahan wajib berkontribusi melalui swadaya masyarakat yang dapat diwujudkan dalam bentuk tenaga kerja, material, uang tunai, konsumsi, dan sebagainya. Swadaya masyarakat diutamakan berasal dari masyarakat mampu di sekitar penerima program. Tujuannya adalah untuk mendorong dukungan dan partisipasi masyarakat dalam pelaksanaan pemugaran rumah keluarga miskin. Menghimpun dana dan material dari masyarakat sebagai pendamping dana stimulan program bedah rumah. Untuk membantu kelancaran dalam pelaksanaan program bedah rumah, di tingkat kabupaten dan di setiap kecamatan seharusnya disiapkan konsultan pendamping dari unsur swasta dan pemerintah. Konsultan ini merupakan tenaga manajerial yang profesional untuk membantu Tim Koordinasi Kabupaten dalam menjaga proses perencanaan dan pelaksanaan program bedah Rumah agar tetap sesuai dengan konsepsi dasar, tujuan dan mekanisme yang telah ditetapkan. Secara umum konsultan memiliki tugas untuk memberikan bimbingan teknis dan administrasi kepada pelaku program bedah rumah di kecamatan dan desa/kelurahan. Pelaku utama dalam program bedah rumah ini sebaiknya adalah masyarakat desa/kelurahan yang ada di sekitar penerima program yang dalam melaksanakan kegiatannya difasilitasi oleh tim pelaksana/Timlak bedah rumah. Pelaku di tingkat kecamatan dan kabupaten berfungsi sebagai fasilitator agar konsepsi dasar, tujuan dan mekanisme program bedah rumah dapat dilaksanakan secara benar.

Pelaku program bedah rumah desa/kelurahan terdiri dari kepala desa/kelurahan, LPM (Lembaga Pemberdayaan Masyarakat) dan tokoh masyarakat. Pelaku program bedah rumah kecamatan terdiri dari Camat, Penanggung jawab Operasional Kegiatan (PJOK), dan Konsultan Pendamping Kecamatan. Pelaku program bedah rumah kabupaten terdiri dari Bupati, Tim Koordinasi Program bedah rumah Kabupaten, dan Konsultan Manajemen Kabupaten. Di samping itu hal terpenting dari pelaksanaan program bedah rumah supaya tidak terjadi penyimpangan dari tujuan dasar adalah perlu disusun standar baku dari calon penerima bantuan sehingga program ini tepat sasaran.

\section{Kendala}

a) Dana

Kendalanya adalah minimnya anggaran pemerintah untuk melakukan atau mengimplementasikan program bedah rumah, jadi wajar saja jika program bedah rumah khusunya di sukorambi ini tidak bisa optimal.

"Semua itu masalahnya ada di dana aja kok mas. Dana dari pusat itu kurang 
mas.jadi kita yang mau distribusikan jadi agak terhambat. Kasarannya itu dananya kurang mulus mas. Jadi kurang cepat untuk geraknya di desa ini mas." (wawancara dengan Kepala Desa Sukorambi, Holili, 20 Mei 2015).

Menurut pengakuan dari sejumlah informan aparat desa, memang dana yang dikucurkan oleh pemerintah tidak sesuai dengan penjadwalannya. Akibatnya banyak sekali program renovasi terhambat dan membuat dana operasional tenaga tukang jadi melonjak. Hal ini yang menjadi salah satu kendala di Desa Sukorambi hingga saat peneliti selesai melakukan penelitian.

b) Komunikasi

Kendala yang kedua, adalah faktor komunikasi yang kurang efektif antara aparata desa dengan masyarakat setempat. Dan antara masyarakat dengan masyarakat. Terjadinya komunikasi yang kurang efektif diantara aparat desa Sukorambi dengan masyarakat terbukti dengan masih adanya orang atau keluarga yang memiliki rumah yang lebih kurang layak huni dibanding sebagian yang telah menerima bantuan program Bedah Rumah desa Sukorambi tersebut.

"Mas wong yang lebih jelek rumahnya masih ada sebenarnya di dusun saya, tapi ya saya tidak tahu apa karena dana kurang tapi paling tidak kan bisa di alihkan dulu ke warga saya karena dusun Manggis ini memang terbanyak rumah yang gak layak huni mas", wawancara dengan kepala dusun Manggis - Sukorambi, M. Sugik pada 20 Mei 2015.

Menurut kepala Dusun yang paling banyak warga yang memiliki hunian paling banyak yang tidak layak huni karena kurangnya komunikasi yang efektif diantara masyarakat di dusun-dusun dengan Aparat Desa setempat.

Selain itu Juga karena adanya disharmonisasi antar warga masyarakat yang saling iri terhadap penerima jadi suasana program ini diselingi dengan nuansa kecemburuan sosial masyarakat. Terbukti dengan pengakuan warga penerima program Bedah Rumah berikut : "Ya ada aja mas orang ga suka saya dapat program ini, padahal saya ya ga mengajukan tapi sudah pilihan pak tinggi, tapi tetep aja disalahkan.yah gitu mas, jadi bikin suasana ga enak saja mas" wawancara dengan Tohar, pada $20 \mathrm{Mei}$ 2015.

Dengan adanya kendala dana dan komunikasi menjadikan program bedah rumah semakin tidak optimal dan kondusif di setiap dusunnya.

\section{Kesimpulan}

Berdasarkan uraian sebelumnya terutama uraian Pada bab hasil penelitian dan pembahasan, dikaitkan dengan rumusan masalah dan tujuan penelitian, maka dapat ditarik beberapa Kesimpulan 
pokok sebagai berikut :

a) Peran pemuka pendapat di desa Sukorambi Jember dalam hal ini Perangkat desa, Kyai/Bindereh dan tokoh masyarakat sangat dirasa oleh masyarakat. Perangkat Desa berperan sebagai penyambung aspirasi masyarakat untuk dapat membantu mewujudkan program bedah rumah hingga rumah tersebut layak huni sesuai dengan target yang tepat sasaran. Kyai/Bindereh berperan sebagai pemuka agama yang mengingatkan syariah Islam dalam program bedah rumah, dan tokoh masyarakat sebagai penggerak masyarakat untuk saling bergotong royong dalam membantu para penerima bantuan program bedah rumah tersebut.

b) Kendala yang dihadapi adalah kurang harminisnya komunikasi antara kia sebagai pemuka pendapat agama dengan perangkat desa sebagai pemuka pendapat yang bersifat legal, sehingga berpoengaruh pada distribusi pendanaan. 
Adi, Isbandi Rukminto, 2000. Psikologi Sosial dan Ilmu Kesejahteraan Sosial, Dasar-. Dasar Pemikiran. Jakarta: PT Raja Grafindo

Ardianto, Elvinaro dkk. 2007. Komunikasi Massa, Suatu Pengantar. Jakarta: Simbiosa Rekatama Media

Arifin, Anwar, 1984. Strategi Komunikasi. Bandung: ARMICO.

Bungin, B. 2001. Analisis Data Penelitian Kualitatif. Jakarta. PT Rajagrafindo Persada. . 2007. Penelitian Kualitatif. Jakarta. Prenada Media Group.

Burke, Peter. 2003. Sejarah dan Teori Sosial, Jakarta: Yayasan Obor Indonesia.

Daft, Richard L. 2006. Manajemen Komunikasi. Jakarta: Penerbit Erlangga

Effendi, Onong Uchjana. 1993. Ilmu, Teori dan Filsafat Komunikasi. Bandung: PT. Citra Aditya Bakti.

Faisal, Sanapiah. 1990. Metodologi Penelitian. Yogyakarta: Kanisius.

Moleong, Lexy. J. 2007. Metodologi Penelitian Kualitatif. Bandung : PT.Remaja Rosdakarya.

Morrisan. 2009. Manajemen Media Penyiaran. Jakarta: Kencana Prenada Media Group.

Mufid, Muhammad. 2005.Komunikasi dan Regulasi Penyiaran. Jakarta: Kencana Hanurawan, Fattah. 2010. Psikologi Sosial. Bandung: PT Remaja Rosdakarya.

Irawan, P. 2006. Penelitian Kualitatif Dan Kuantitatif Untuk Ilmu-Ilmu Sosial. Jakarta:Departemen Ilmu Administrasi FISIP UI.

Jefkins, Frank. 1996. Periklanan. Jakarta: PT Erlangga.

Kartono, 1990. Psikologi Umum. Bandung: UPI Press. 
Kreitner, $R$ dan Kinicki. 2005. Organizational Behaviour. Jakarta: PT Salemba

Rakhmat, Jalaluddin. 2007. Psikologi Komunikasi. Bandung: Remaja Rosda Karya.

Rahmad, Salahuddin. 2000. Psikologi Komunikasi. Bandung: PT. Remaja Rosdakarya. 